\title{
Studies on the Formation of Nitrosamines I.
}

\author{
Kinetical Studies on the Nitrosation of Piperidine and Morpholine
}

(Received January 8, 1974)

\author{
Takashi Yamada, Miyako Yamamoto and Akio Tanimura \\ (Department of Food Additives, National Institute of Hygienic Sciences: 18-1, \\ Kamiyoga 1-chome, Setagaya-ku, Tokyo)
}

\begin{abstract}
Rates of formation of nitrosopiperidine (NP) and nitrosomorpholine (NM) were studied. Initial rates of formation of NP from piperidine and sodium nitrite were calculated from the absorbance at $260 \mathrm{~nm}$ after decomposition of nitrite with sulfamic acid. They were proportional to [piperidine] $\left[\mathrm{NaNO}_{2}\right]^{2}$ both at $\mathrm{pH} 4.2$ and 3.0. Initial rates of formation of NM from morpholine and sodium nitrite at $\mathrm{pH} 4.2$ and 3.0 were also proportional to [morpholine] $\left[\mathrm{NaNO}_{2}\right]^{2}$.

The effect of $\mathrm{SCN}^{-}$on the formation of $\mathrm{NP}$ at various $\mathrm{pH}$ values was also studied. $\mathrm{SCN}^{-}$in concentration of $15 \mathrm{~mm}$ accelerated the initial rate of formation of NP by three times compared with one in the absence of $\mathrm{SCN}^{-}$at $\mathrm{pH} 1.25$, but accelerated only by 1.2 times at $\mathrm{pH}$ 3.5. According to Boyland et al., the content of $\mathrm{SCN}^{-}$in human saliva was estimated to be $2 \sim 5.7 \mathrm{mM}$. Therefore, $\mathrm{SCN}^{-}$in human saliva does not seem so much effective to the rate of formation of NP.
\end{abstract}

It is well known that nitrosamines could be formed in foods or in the stomach of rats or rabbits by the action of nitrite on the secondary amines present in foods during storage, cooking, or digestion. Many of them are shown to be carcinogenic $^{1), 2)}$, and dimethylnitrosamine is one of the most potential carcinogenic nitrosamine among them. Besides, dimethylamine, which is one of the precursor of dimethylnitrosamine, is contained in many kinds of foodstuffs, especially in marine fish and fish products ${ }^{3), 4)}$. Although dimethylamine is nitrosated relatively slowly ${ }^{5,6)}$, more rapidly nitrosatable secondary amines might be more potently hazard to human health. So, it is important to estimate the rates of nitrosation of various secondary amines.

Piperidine is detected in fish $^{7), 8)}$, soy bean ${ }^{9)}$, and tobacco smoke ${ }^{10)}$, and it could be nitrosated to nitrosopiperidine (NP) which is carcinogenic to $\operatorname{rats}^{11) \sim 13)}$ and hamsters ${ }^{14)}$. Alam et al., reported in vitro formation of NP from piperidine and nitrite $^{15)}$ or nitrate ${ }^{16)}$ in the stomach or the small intestine of rats. Mirvish ${ }^{17)}$ described in his paper that the rates of nitrosation of secondary amines depend on the $\mathrm{pK}_{\mathrm{a}}$ values of the amines and he also described that the rates of the formation of nitrosamines from secondary amines and nitrite are proportional to the concentration of secondary amines and the square of the nitrite concentration. There are some papers showing that the rates of nitrosation of dimethylamine and other secondary amines are proportional to the square of the nitrite concentration ${ }^{18), 18)}$. On the other hand, Friedman reported that the rates of nitrosation of dimethylamine and sarcosine are proportional to nitrite concentration $^{20)}$.

In this paper, the effects of the concentration of nitrite and piperidine, and the effect of thiocyanate on the formation of NP are described. The effect of concentration of nitrite and morpholine, whose $\mathrm{pK}_{\mathrm{a}}$ value is greatly different from that of piperidine, on the formation of $N$-nitrosomorpholine (NM) is also described.

\section{Methods}

1. Identification of the products

Sodium nitrite $(200 \mathrm{mM})$ and piperidine (20 
$\mathrm{mM}$ ) in $1 \mathrm{M}$ sodium acetate-hydroshloric acid buffer solution, $\mathrm{pH} 3.0$, were incubated at $37^{\circ} \mathrm{C}$ for $1 \mathrm{hr}$. The reaction was performed in a final volume of $20 \mathrm{ml}$. Four gram of potassium carbonate were added to the reaction mixture and extracted three times with each $10 \mathrm{ml}$ of dichloromethane. The combined extract was concentrated to about $1 \mathrm{ml}$ and used for further analyses.

Thin layer chromatography was performed on silicagel spotfilm (Tokyo Kasei Kogyo Co. Ltd.). The developing solvents used were hexane-ether-dichloromethane, $(2: 3: 10)$ and chloroform-methanol-water, $(65: 25: 4)$. The spots were visualyzed with Griess reagent or ninhydrin reagent after spraying $30 \%$ acetic acid and exposing to ultraviolet light (253.6 $\mathrm{nm}$ ) for $10 \mathrm{~min}$. When Wakogel UA plates (Wako Pure Chemical Ind., Ltd.) containing inorganic fluorescent indicator were used, the spots could be seen directly with ultraviolet light.

The authentic NP was purchased from Eastman Organic Chemicals.

In the case of $\mathrm{NM}$ formation, $3 \mathrm{mM}$ of morpholine and $15 \mathrm{mM}$ of nitrite were used and the other procedures were the same as described above.

The gas-liquid chromatograph used was a Yanaco Model G 80 equipped with an FID detector and $2.25 \mathrm{~m}$ glass column packed with $10 \% \mathrm{PEG}$ plus $3 \% \mathrm{KOH}$ on Gas-chrom $\mathrm{P}$. Column temperature was $148^{\circ} \mathrm{C}$.

\section{Determination of nitrosamines}

The concentrations of NP and NM were measured spectrophotometrically at $260 \mathrm{~nm}$ using $\varepsilon_{280}=1450$ for NP and $\varepsilon_{280}=3540$ for $\mathrm{NM}^{23)}$, respectively. Although, $\lambda_{\max }$ for $\mathrm{NP}$ is $234 \sim 235 \mathrm{~nm}(\varepsilon=8300)$ and for NM is 235 $\mathrm{nm}$, the strong absorption of nitrite that might remain in the reaction mixture makes it simpler to use $260 \mathrm{~nm}$.

\section{Measurement of the rate of formation} of NP

Sodium nitrite solution was added to piperidine solution in acetate-hydrochloric acid buffer solution kept at $37^{\circ} \mathrm{C}$. The $\mathrm{pH}$ of the reaction mixture was adjusted to $\mathrm{pH} 4.2$ or 3.0 when reaction was started. The final concentration of piperidine was $10 \sim 25 \mathrm{~mm}$ and that of sodium nitrite was $100 \sim 200 \mathrm{~mm}$. Five $\mathrm{ml}$ of the aliquots were withdrawn periodically from the reaction mixture and stop the reaction by the addition of a large excess of sulfamic acid. Optical density at $260 \mathrm{~nm}$ was measured and the initial rate of the formation of NP was calculated. For the experiments on the effect of thiocyanate, $\mathrm{NH}_{4} \mathrm{SCN}$ was used in the concentration of 15 or $2.5 \mathrm{~mm}$.

\section{Measurement of the rate of formation} of NM

The experimental procedures were very similar to that described in measurement of the rate of formation of NP. The differences were that the final concentration of morpholine used was $1 \sim 3 \mathrm{mM}$ and that of sodium nitrite

Table 1. Initial Rates of Nitrosation of Piperidine with Nitrite

Piperidine was dissolved in acetate-hydrochloride buffer and kept at $37^{\circ} \mathrm{C}$. Sodium nitrite solution was added to start the reaction. The final volume of the reaction mixture was $20 \mathrm{ml}$, and the $\mathrm{pH}$ values and concentration shown in the table were the final values. At regular time intervals, $5 \mathrm{ml}$ of the sample solution was withdrawn and stop the reaction by the addition of a large excess of sulfamic acid. Then the optical density at $260 \mathrm{~nm}$ was measured and the initial rate of formation of NP was calculated using the $\varepsilon$ value of 1450 .

\begin{tabular}{c|c|c|c|c|c}
\multicolumn{2}{c|}{} & \multicolumn{3}{|c}{$\mathrm{pH} 3.0$} \\
\hline $\begin{array}{c}\text { Piperidine } \\
(\mathrm{mM})\end{array}$ & $\begin{array}{c}\mathrm{NaNO}_{2} \\
(\mathrm{mM})\end{array}$ & $\begin{array}{c}\text { Initial rate } \\
(\mathrm{mM} / \mathrm{hr})\end{array}$ & $\begin{array}{c}\text { Piperidine } \\
(\mathrm{mM})\end{array}$ & $\begin{array}{c}\mathrm{NaNO}_{2} \\
(\mathrm{mM})\end{array}$ & $\begin{array}{c}\text { Initial rate } \\
(\mathrm{mM} / \mathrm{hr})\end{array}$ \\
\hline 10 & 100 & 0.052 & 10 & 150 & 0.760 \\
20 & 100 & 0.115 & 10 & 200 & 1.243 \\
25 & 100 & 0.137 & 15 & 200 & 1.851 \\
25 & 150 & 0.247 & 25 & 200 & 3.002 \\
25 & 200 & 0.461 & & &
\end{tabular}


was $5 \sim 15 \mathrm{mM}$.

\section{Results}

\section{Identification of the products}

The extract of the reaction mixture of piperidine and nitrite gave only one spot coinciding with authentic NP on thin layer chromatograms developed with two different solvent systems and detected by Griess reagent or ultraviolet absorption. The extract gave two spots on thin layer chromatograms treated with ninhydrin reagent, one of which was coincident with NP and the other with piperidine. The extract gave also only one peak whose retention time was coincident with NP (11 min) on the gas chromatogram. Under this condition, the peak of unreacted piperidine was not separated from that of the solvent. The ultraviolet absorption curve of the product was the same as that of NP.

From these results, it is clear that the product is only NP and that the optical density at $260 \mathrm{~nm}$ is proportional to the amount of NP. Therefore, the amount of NP was measured with optical density at $260 \mathrm{~nm}$ in the following experiments.

The extract from the reaction mixture of morpholine and sodium nitrite gave also one spot on the thin layer chromatograms and gave one peak $(12 \mathrm{~min} 20 \mathrm{sec})$ on the gas chromatogram.

\section{Nitrosation of piperidine}

The reaction proceeded linearly for $20 \mathrm{~min}$ at $\mathrm{pH} 3.0$ and for $2 \mathrm{hr}$ at $\mathrm{pH} 4.2$, respectively. The amount of NP formed reached to about $4 \%$ of initial piperidine. Table 1 shows the initial rates of NP formation varying the stoichiometric concentration of piperidine and nitrite at $\mathrm{pH} 4.2$ and 3.0 .

With the constant concentration of sodium nitrite at $100 \mathrm{mM}$ at $\mathrm{pH} 4.2$, the relationship between piperidine concentration and the initial rate of nitrosation was first order (Fig. 1).

In similar experiments, with the constant concentration of piperidine at $25 \mathrm{mM}$, the initial rate at $\mathrm{pH} 4.2$ was second order with respect to sodium nitrite concentration (Fig. 2).

At $\mathrm{pH} 3.0$ and 4.2 , the rates of nitrosation of piperidine depended upon the piperidine concentration and the square of the nitrite concentration as shown in Fig. 3.

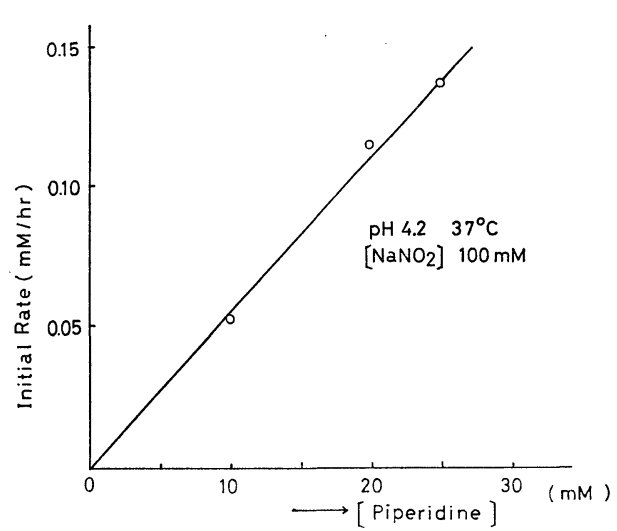

Fig. 1. Effect of piperidine concentration on nitrosation

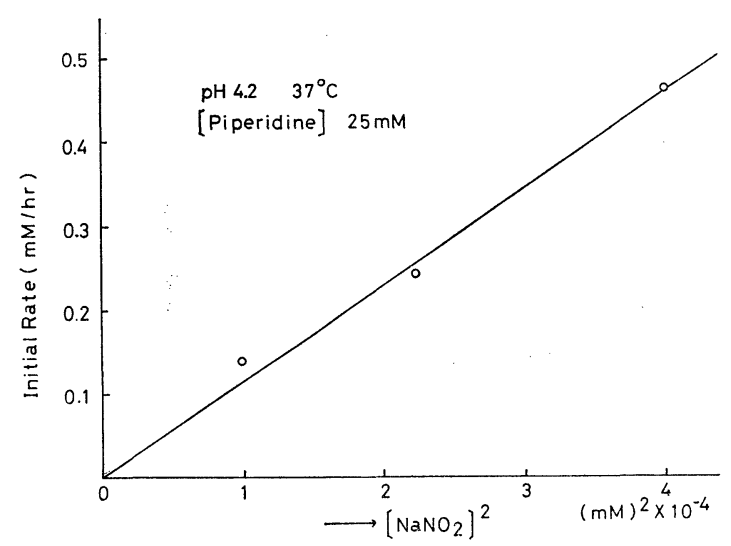

Fig. 2. Effect of $\mathrm{NaNO}_{2}$ concentration on nitrosation

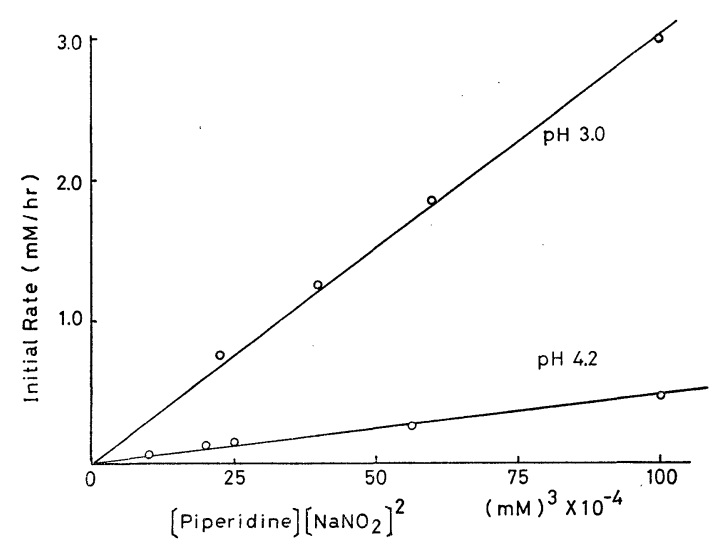

Fig. 3. Third-order rate plot for nitrosation of piperidine 
Table 2. Initial Rates of Nitrosation of Morpholine with Nitrite

Experimental procedures were the same as described in the legend of Table 1. In this case, the $\varepsilon$ value of 3450 was used for the estimation of NM from the optical density at $260 \mathrm{~nm}$.

\begin{tabular}{c|c|c|c|c|c}
\multicolumn{2}{c|}{} & \multicolumn{3}{|c}{$\mathrm{pH} 3.0$} \\
\hline $\begin{array}{c}\text { Morpholine } \\
(\mathrm{mM})\end{array}$ & $\begin{array}{c}\mathrm{NaNO}_{2} \\
(\mathrm{mM})\end{array}$ & $\begin{array}{c}\text { Initial rate } \\
(\mathrm{mM} / \mathrm{hr})\end{array}$ & $\begin{array}{c}\text { Morpholine } \\
(\mathrm{mM})\end{array}$ & $\begin{array}{c}\mathrm{NaNO}_{2} \\
(\mathrm{mM})\end{array}$ & $\begin{array}{c}\text { Initial rate } \\
(\mathrm{mM} / \mathrm{hr})\end{array}$ \\
\hline 1 & 10 & 0.029 & 1 & 5 & 0.059 \\
2 & 10 & 0.054 & 1 & 10 & 0.171 \\
2 & 15 & 0.127 & 1 & 15 & 0.305 \\
3 & 10 & 0.087 & 2 & 15 & 0.593
\end{tabular}

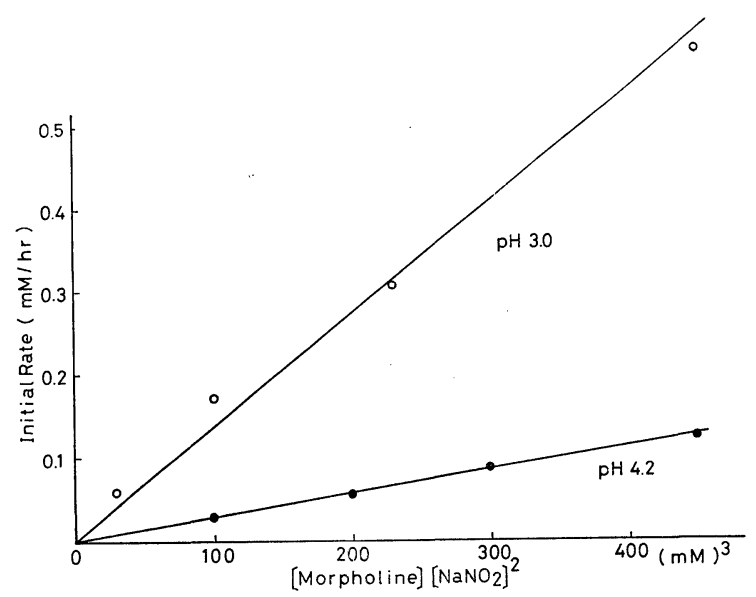

Fig. 4. Third-order rate plot for nitrosation of morpholine

\section{Nitrosation of morpholine}

The initial rates of nitrosation of morpholine at $\mathrm{pH} 3.0$ and 4.2 varying the concentrations of morpholine and nitrite were shown in Table

2. The amount of NM formed was proportional to reaction period while the concentration of NM reached about to $10 \%$ of initial morpholine.

The rate was also dependent upon the morpholine concentration and the square of the nitrite concentration (Fig. 4).

4. The effect of thiocyanate on nitrosation

\section{of piperidine}

The effect of thiocyanate on nitrosation of piperidine was studied at a variety of $\mathrm{pHs}$ of the incubation mixture, which contained $10 \mathrm{mM}$ of piperidine, $100 \mathrm{~mm}$ of sodium nitrite and 15 $\mathrm{mM}$ of ammonium thiocyanate. As shown in Fig. 5, compared to the rate of nitrosation of piperidine without thiocyanate ion, the rate of

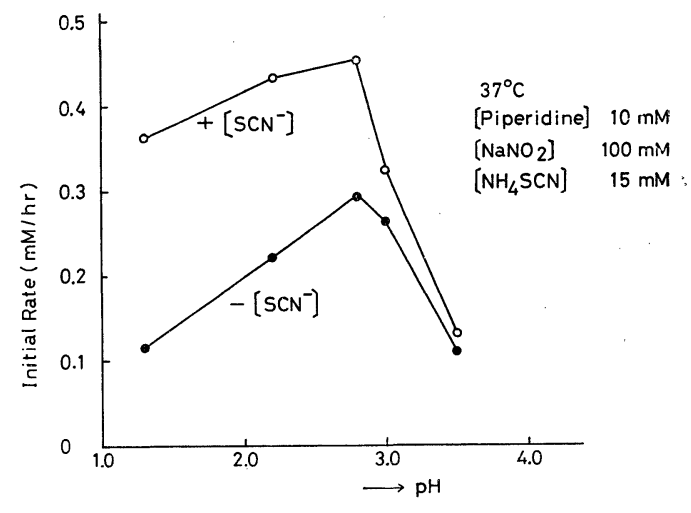

Fig. 5. Effect of $\mathrm{pH}$ on the initial rate of nitrosation fo piperidine with and without thiocyanate

nitrosation of piperidine with thiocyanate ion was accelerated with increasing acidity of the incubation mixture. Formation of NP was accelerated by 3.18 times at $\mathrm{pH} 1.3,1.97$ times at $\mathrm{pH} 2.2,1.24$ times at $\mathrm{pH} 3.0$ and 1.08 times at $\mathrm{pH}$ 3.5. When thiocyanate concentration was $2.5 \mathrm{~mm}$ at $\mathrm{pH} 3.0, \mathrm{NP}$ formation was accelerated only by 1.08 times.

\section{Discussion}

Rate constants of the reaction could be calculated from the following equation: Rate $=k$ [total amine $\times\left[\right.$ total nitrite ${ }^{2}$ and from the data listed in Tables 1 and 2.

At $\mathrm{pH} 4.2, \quad k_{\text {piperidine }}=0.46 \mathrm{~L}^{2} / \mathrm{mole}^{2} \cdot \mathrm{hr}$, $k_{\text {morpholine }}=2.82 \times 10^{2} \mathrm{~L}^{2} / \mathrm{mole}^{2} \cdot \mathrm{hr}$, and at $\mathrm{pH}$ $3.0, k_{\text {piperidine }}=3.17 \mathrm{~L}^{2} / \mathrm{mole}^{2} \cdot \mathrm{hr}, k_{\text {morpholine }}$ $=1.28 \times 10^{3} \mathrm{~L}^{2} / \mathrm{mole}^{2} \cdot \mathrm{hr}$. The values at $\mathrm{pH}$ 3.0 measured at $37^{\circ} \mathrm{C}$ are comparable with $k_{\text {piperidine }}=1.62 \mathrm{~L}^{2} / \mathrm{mole}^{2} \cdot \mathrm{hr}$ and $k_{\text {morpholine }}$ $=8.88 \times 10^{2} \mathrm{~L}^{2} / \mathrm{mole}^{2} \cdot \mathrm{hr}$ that have been shown 
by Mirvish ${ }^{17)}$ that measured at $25^{\circ} \mathrm{C}$.

$\mathrm{He}$ also reported that the optimum $\mathrm{pH}$ for nitrosation of piperidine was $\mathrm{pH} 3.0$, but in Fig. 6, it was a little lower than $\mathrm{pH} 3.0$ and was near $\mathrm{pH}$ 2.8. Recently, Lane and Bailey ${ }^{21)}$ reported that the optimum $\mathrm{pH}$ for nitrosation of dimethylamine in human gastric juice was a little lower than that reported by Mirvish. One of the reasons of these differences might be interpreted as the contribution of nitrosyl chloride present in the buffer used.

There are some papers showing that thioycanate ion present in human saliva as a natural component is an effective accelerator of nitrosation of $N$-methyl aniline and morpholine ${ }^{22), 23)}$. Thiocyanate content in human saliva is reported to be $2 \sim 5.7 \mathrm{~mm}$. But, from the data described above, thiocyanate in human saliva does not seem to play an important role in nitrosation of piperidine in human stomach.

The authors are indebted to Emeritus professor M. Ishidate of Tokyo University and Dr. I. Kawashiro, Director of National Institute of Hygienic Sciences, for their advices and encouragements.

This work was supported by Cancer Research Fund (1973) from the Ministry of Welfare and Special Research Fund from Naional Institute of Hygienic Sciences.

\section{References}

1) Druckrey, H., Preussmann, R.: Z. Krebsforsch., 69, 103 (1967).

2) Magee, P. N., Barnes, J. M.: Adv. in Cancer Res., 10, 163 (1967).

3) Kawamura, T., Sakai, K., Miyazawa, F., Wada, H., Ito, Y., Tanimura, A.: J. Food Hyg. Soc. Japan, 12, 192 (1971).

4) Kawamura, T., Sakai, K., Miyazawa, F., Wada, H., Ito, Y., Tanimura, A.: ibid., 12, 394 (1971).
5) Mirvish, S.S.: J. Nat. Cancer Inst., 44, 633 (1970).

6) Sakai, A., Tanimura, A.: J. Food Hyg. Soc. Japan, 12, 170 (1971).

7) Golovnya, R. V., Mironov, G. A., Zhuravleva, I. L.: Zh. Anal. Khim., 22, 956 (1967); Chem. Abstr., 70, 27745d (1969).

8) Shimomura, M., Yoshimatsu, F., Matsumoto, F.: J. Home Economics, 22, 20 (1971).

9) Arai, S., Suzuki, H., Fujimaki, M., Sakura, Y.: Agr. Biol. Chem., 30, 863 (1966).

10) Neurath, G., Duenger, M., Geve, J., Luettich, W., Wichern, H.: Beitr. Tabakforsch., 3, 563 (1966); Chem. Abstr., 67, 8792 p. (1967).

11) Druckrey, H., Preussmann, R., Schmähl, D., Müller, M.: Naturwissenschaften, 48, 134 (1961).

12) Druckrey, H., Ivanokovic, S., Mennel, H. D., Preussmann, R.: Z. Krebsforsch., 66, 138 (1964).

13) Boyland, E., Roe, F. J.C., Gorrod, J. M., Mitchley, B. C. V.: Brit. J. Cancer, 18, 265 (1964).

14) Dontenwill, W., Mohr, U.: Z. Krebsforsch., 65, 166 (1962).

15) Alam, B.S., Saporoschetz, I. B., Epstein, S. S., Nature, 232, 116 (1971).

16) Alam, B.S., Saporoschetz, I. B., Epstein, S. S.: ibid., 232, 199 (1971).

17) Mirvish, S. S.: Proc. 2nd International Symp. of the Princess Takamatsu Cancer Reseach Fund., p. 279 (1973).

18) Hughes, E. D., Ingold, C. K., Ridd, J.H.: J. Chem. Soc., 77 (1958).

19) Larkworthy, L. F.: ibid., 3304 (1959).

20) Friedman, M. A.: Bull. Environ. Contam. Toxicol., 8, 375 (1972).

21) Lane, R.P., Bailey, M. E.: Fd. Cosmet. Toxicol., 11, 851 (1973).

22) Boyland, E., Nice, E., Williams, K.: ibid., 9, 639 (1971).

23) Fan, T.Y., Tannenbaum, S. R.: J. Agr. Food Chem., 21, 237 (1973). 